\title{
Somatotropic axis genes are expressed before pituitary onset during zebrafish and sea bass development
}

\author{
Besseau Laurence 1, 2, * , Fuentes Michael 1,2, Sauzet Sandrine 1, 2, Beauchaud Marilyn ${ }^{3}$, \\ Chatain Beatrice ${ }^{4}$, Coves Denis ${ }^{4}$, Boeuf Gilles ${ }^{1,2,5}$, Falcon Jack ${ }^{1,2}$
}

\author{
1 Univ Paris 06, Lab Arago, F-66650 Banyuls Sur Mer, France. \\ ${ }^{2}$ CNRS UMR 7232, F-66650 Banyuls Sur Mer, France. \\ 3 Univ Lyon St Etienne, Equipe Neuroethol Sensorielle, ENES CNPS, CNRS UMR 8195, F-42023 St \\ Etienne 2, France. \\ 4 Stn Ifremer Palavas, UMR Intrepid 110, F-34250 Palavas Les Flots, France. \\ ${ }^{5}$ MNHN, F-75005 Paris, France. \\ * Corresponding author : Laurence Besseau, email address : besseau@obs-banyuls.fr \\ michael.fuentes@obs-banyuls.fr ; sandrine.sauzet@univ-lyon1.fr ; beauchaud@univ-st-etienne.fr ; \\ Beatrice.Chatain@ifremer.fr ; denis.coves@ifremer.fr ; gilles.boeuf@obs-banyuls.fr ; \\ falcon@obs-banyuls.fr
}

\begin{abstract}
:
The somatotropic axis, or growth hormone-insulin-like growth factor-1 (GH-IGF-1) axis, of fish is involved in numerous physiological process including regulation of ionic and osmotic balance, lipid, carbohydrate and protein metabolism, growth, reproduction, immune function and behavior. It is thought that GH plays a role in fish development but conflicting results have been obtained concerning the ontogeny of the somatotropic axis. Here we investigated the developmental expression of GH, GH-receptor (GHR) and IGF-1 genes and of a GH-like protein from fertilization until early stages of larval development in two Teleosts species, Danio rerio and Dicentrarchus labrax, by PCR, in situ hybridization and Western blotting. GH, GHR and IGF-1 mRNA were present in unfertilized eggs and at all stages of embryonic development, all three displaying a similar distribution in the two species. First located in the whole embryo (until $12 \mathrm{hpf}$ in zebrafish and $76 \mathrm{hpf}$ in sea bass), the mRNAs appeared then distributed in the head and tail, from where they disappeared progressively to concentrate in the forming pituitary gland. Proteins immunoreactive with a specific sea bass anti-GH antibody were also detected at all stages in this species. Differences in intensity and number of bands suggest that protein processing varies from early to later stages of development. The data show that all actors of the somatotropic axis are present from fertilization in these two species, suggesting they plays a role in early development, perhaps in an autocrine/paracrine mode as all three elements displayed a similar distribution at each stage investigated.
\end{abstract}




\section{Highlights}

- Targets the simultaneous presence of the 3 components of the somatotropic axis in developing embryos of two Teleost fish. GH, GH receptors and IGF-1 are expressed in unfertilized eggs from zebrafish and sea bass. After fertilization expression of all three components is detected before pituitary differentiation. $\mathrm{GH}$ gene expression is accompanied by $\mathrm{GH}$ protein detection. Clarifies previous contradictory results on this matter.

Keywords : Growth hormone GH, Insulin-like growth factor-1 IGF-1, Pituitary, Development, Zebrafish, Sea bass 


\section{Introduction}

The pituitary constitutes an anatomical and physiological link between the nervous and endocrine systems. In fish, it controls diverse physiological functions including somatic growth, metabolism, osmoregulation, reproduction, and behavior (Herzog et al., 2003). Among the hormones produced by the pituitary, growth hormone $(\mathrm{GH})$ belongs to a hormonal superfamily which also includes somatolactin (SL) and prolactin (PRL). In fish GH has

* Corresponding author. Address: Laboratoire Arago, UPMC CNRS UMR 7232 Avenue de Fontaulé, 66650 Banyuls-sur-Mer, France.

E-mail addresses: besseau@obs-banyuls.fr (B. Laurence), michael.fuentes@ obs-banyuls.fr (F. Michaël), sandrine.sauzet@univ-lyon1.fr (S. Sandrine), beauchaud@ univ-st-etienne.fr (B. Marilyn), Beatrice.Chatain@ifremer.fr (C. Béatrice), denis. coves@ifremer.fr (C. Denis), gilles.boeuf@obs-banyuls.fr (B. Gilles), falcon@ obs-banyuls.fr (F. Jack).

1 Present address: Université Claude Bernard Lyon1-CNRS UMR 5558, Biométrie \& Biologie Évolutive, Bat Mendel, 43 bd du 11 novembre 1918, 69622 Villeurbanne,

to be correcected, names and surnames have been inverted pleiotropic actions, including ionic and osmotic balance, reproduction and immune function, as well as different aspects of behavior (Perez-Sanchez, 2000; Reinecke et al., 2005).

The general organization of the somatotropic axis or growth hormone-insulin-like growth factor-1 (GH-IGF-1) axis is similar between mammals and fish, and includes GH, GH receptor (GHR), insulin-like growth factor (IGF), IGF receptor (IGF-R) and IGF binding protein (Gabillard et al., 2003; Moriyama et al., 2000; Reinecke, 2010). GH is expressed and synthesized in somatotropic cells from the adenohypophysis in adults, but expression has also been detected in several extra hypophyseal tissues (Miura et al., 2011). Because of its involvement in growth, GH has also been studied during development. Studies in birds and mammals indicated GH gene expression may appear before pituitary differentiation (Murphy and Harvey, 2001; Pantaleon et al., 1997). In fish, there is evidence that it is transcribed and translated early during development either before or after pituitary differentiation (Ayson et al., 1994; Herzog et al., 2003; Ozaki et al., 2006; Yang et al., 1999). However, the role GH plays during fish embryonic and

0016-6480/\$ - see front matter @ 2013 Published by Elsevier Inc. http://dx.doi.org/10.1016/j.ygcen.2013.08.018 to be corrected, name and surname have been inverted

Please cite this article in press as: Laurence, B., et al. Somatotropic axis genes are expressed before pituitary onset during zebrafish and sea bass development. Gen. Comp. Endocrinol. (2013), http://dx.doi.org/10.1016/j.ygcen.2013.08.018 
larval development remains unclear (Fuentes et al., 2008; Gabillard et al., 2003; Zhu et al., 2007). A clear-cut picture cannot yet be provided because the studies relate to a very limited number of species, focusing either on mRNA or on protein detection, seldom on both, and barely consider the somatotropic system as a whole (i.e., the GH/GHR/IGF system). This probably accounts for the differences observed from a study to another. In addition, conflicting results have been reported concerning a same species (e.g., in trout Jones et al., 2001; Yang et al., 1999). More information is thus clearly needed to further elucidate the role GH/IGF play in fish larval growth and differentiation. In the present study we investigated the expression of the somatotropic axis genes encoding $\mathrm{GH}$, GHR and IGF-1 during early stages of development in the zebrafish Danio rerio and sea bass Dicentrarchus labrax. These species were chosen because they have high value for the scientific community (zebrafish) as well as for the farming industry (sea bass), and tools are available for both species. A better knowledge of the GH/GHR/ IGF system may help improving the conditions for embryo and larval development in these species. Here we investigated the expression of GH, GHR and IGF-1 transcripts at different stages of early development, including unfertilized eggs. Localization of the sites of expression was achieved using whole-mount in situ hybridization. Finally, we developed an antibody directed against $\mathrm{GH}$ protein from sea bass in order to see whether the presence of transcripts was associated with GH protein production.

\section{Material and methods}

\subsection{Animals}

Adult zebrafish, D. rerio were reared at $28^{\circ} \mathrm{C}$ on a $12 \mathrm{~h}$ light $/ 12 \mathrm{~h}$ dark (12L/12D) cycle. Fertilized eggs were incubated under similar LD and temperature conditions. Mature adult sea bass, D. labrax were reared at the "Station IFREMER" of Palavas (France). After fertilization, embryos and larvae were reared under a 19L/5D cycle and natural temperature. Embryos to be used in whole-mount in situ hybridization (ISH) studies were placed at 24 hours post-fertilization (hpf) in $0.2 \mathrm{mM}$ phenylthiourea to prevent pigmentation.

\subsection{Eggs, embryos and larvae sampling}

Unfertilized eggs as well as embryos and larvae were collected at different times of their development. They were either frozen in liquid nitrogen (Western blotting or PCR purposes) or immersed in RNA Later solution (Ambion Biosystems; Austin, TX) (PCR purposes only); they were then stored at $-80^{\circ} \mathrm{C}$. Other samples were fixed overnight in freshly prepared $4 \%$ paraformaldehyde (PFA) in phosphate buffer saline (PBS) at $+4{ }^{\circ} \mathrm{C}$, for ISH or immunocytochemical (ICC) studies. ISH samples were stored in methanol at $-20^{\circ} \mathrm{C}$. ICC samples were cryo-protected by successive baths of glycerine/sucrose in PBS at $+4{ }^{\circ} \mathrm{C}$ as follows: $2 \times 30 \mathrm{~min}$ in $4 \%$ sucrose, $30 \mathrm{~min}$ in $5 \%$ glycerine $10 \%$ sucrose, $1 \mathrm{~h}$ in $10 \%$ glycerine/15\% sucrose, and overnight in $10 \%$ glycerine/ $30 \%$ sucrose; finally they were frozen in $-50^{\circ} \mathrm{C}$ isopentane.

\subsection{Amplification from different developmental stages}

The sequences of the genes investigated in this study were available from the data bases (Supplementary Table 1; partial sequence in the case of dIIGF-1). We therefore designed specific primer sets for further amplification from the respective cDNAs (Supplementary Table 1). Total RNA of embryos and larvae from each developmental stage was extracted using the Trizol ${ }^{\circledR}$ method (Invitrogen; Cergy Pontoise, France). One $\mu \mathrm{g}$ of total RNA was incubated with 1 unit of DNAse I (Roche; Meylan, France) for 30 min at $37^{\circ} \mathrm{C}$. After DNAse inactivation (10 min at $65^{\circ} \mathrm{C}$ ), RNA was reverse transcribed using Powerscript Reverse transcriptase (Invitrogen; Cergy Pontoise, France) in a total volume of $20 \mu \mathrm{l}$. The polymerase chain reaction (PCR) was performed on the obtained CDNA in a total volume of $25 \mu$ l, using the primers and conditions described in Supplementary Tables 1 and 2, respectively. In the controls, the template cDNA was replaced by water. The PCR products were loaded in a $2 \%$ agarose gel, in the presence of DNA size markers (DNA ladder 1 kb, Promega; Charbonnières, France). Fragments of the expected size were extracted, subcloned in a pGEM-T Easy vector (Promega; Charbonnières, France) and sequenced by Cogenics (Meylan, France) for verification.

\subsection{Western blots}

Total protein content from pooled sea bass larvae were sonicated at $4{ }^{\circ} \mathrm{C}$ in PBS solution containing protease inhibitors (Complete Solution; Roche, Meylan, France). A pool of 3 adult sea bass pituitaries was used as a positive control. Protein content in the homogenates was quantified using the Bradford assay and bovine serum albumin (BSA) as a standard Bradford, 1976.

Proteins were resolved on a $12.5 \%$ polyacrylamine gel in a Tris/ glycine electrophoresis system (Biorad; Marnes-La-Coquette, France). Gels were run at $100 \mathrm{~V}$ for $1 \mathrm{~h}$. Markers (Precision-Plus Protein Standard's; Biorad) were used to determine the molecular weight of the proteins. The proteins were transferred on a polyvinylidene Immobilon-P membrane (Millipore; Molsheim, France) in a Tris-glycine $/ 20 \%$ methanol buffer with a semi-dry Fisherbrand blotting system (Thermofisher; Illkirsch, France) following the manufacturer's protocol. After transfer, the membranes were placed for $2 \mathrm{~h}$ PBS ( $\mathrm{pH} 7.4$ ) containing 10\% nonfat dry milk and $0.2 \%$ Tween (PBST). They were then incubated overnight ( $18 \mathrm{~h}$ at $4{ }^{\circ} \mathrm{C}$ ) in the primary antibody dilution $(1 / 5000)$ in PBS containing $1 \mathrm{mg}$ BSA fraction V. After washing in PBST and then in PBS, the membranes were submitted to horseradish peroxydase conjugated goat antirabbit IgG $(0.0083 \mu \mathrm{g} / \mathrm{ml}$ in PBST containing $0.1 \%$ normal goat serum). The membranes were then washed in PBST $(3 \times 10 \mathrm{~min})$ and in PBS $(3 \times 5 \mathrm{~min})$ and immunodetection was performed using the $\mathrm{ECL}^{+}$detection kit (Life Technologies, Saint Aubin, France), and finally observed under a Vilbert Lourmat apparatus (Marne-la-Vallée, France).

The antibody directed against sea bass $\mathrm{GH}$ (dlGH-antibody) was obtained and validated by Eurogentec (Liège, Belgium) by rabbit immunization against two peptide sequences from sea bass $\mathrm{GH}$ (GANQDGAEMFPDSSTL and WEFPSRSLSVPGAARN).

\subsection{In situ hybridization (ISH)}

For all species, embryos and larvae were fixed overnight by immersion in $4 \%$ paraformaldehyde in PBS at $4{ }^{\circ} \mathrm{C}$, washed in buffer, transferred to $100 \%$ methanol and stored at $-20^{\circ} \mathrm{C}$. Wholemount ISH was performed using digoxigenin-labeled riboprobes made using a commercially available kit (Roche, Meylan, France) according to the manufacturer's instructions. The antisense and sense probes (Supplementary Table 2) were generated using a cDNA fragment of the genes of interest. Sea bass IGF-1 antisense and sense probes were produced from a cDNA fragment (291 bp) obtained by a $5^{\prime}, 3^{\prime}$-rapid amplification of cDNA ends (RACE)-PCR (SMART RACE cDNA Amplification kit, Clontech; Mountain View, CA) with the specific primer dIIGF-1-F GGTCGACACGCTGCAGTTTGTG under the following conditions: $95^{\circ} \mathrm{C}(1 \mathrm{~min})$, then 10 cycles of $94^{\circ} \mathrm{C}(20 \mathrm{~s}), 67^{\circ} \mathrm{C}(1 \mathrm{~min}), 68^{\circ} \mathrm{C}(1 \mathrm{~min})$, followed by 20 cycles of $94^{\circ} \mathrm{C}(10 \mathrm{~s}), 65^{\circ} \mathrm{C}(1 \mathrm{~min}), 68^{\circ} \mathrm{C}(90 \mathrm{~s})$, then $68^{\circ} \mathrm{C}$ ( $7 \mathrm{~min}$ ) and finally $4{ }^{\circ} \mathrm{C}$. The amplified fragment was purified, subcloned in PGEM-T Easy Vector (Promega, Charbonnières, France) and sequenced. 


\section{D. rerio GH}


Fig. 2. Whole-mount ISH for GH mRNA during zebrafish development. s: sense probe; as: antisense probe. Hours post-fertilization are indicated at the bottom of the picture.

\section{D. labrax GH}


s
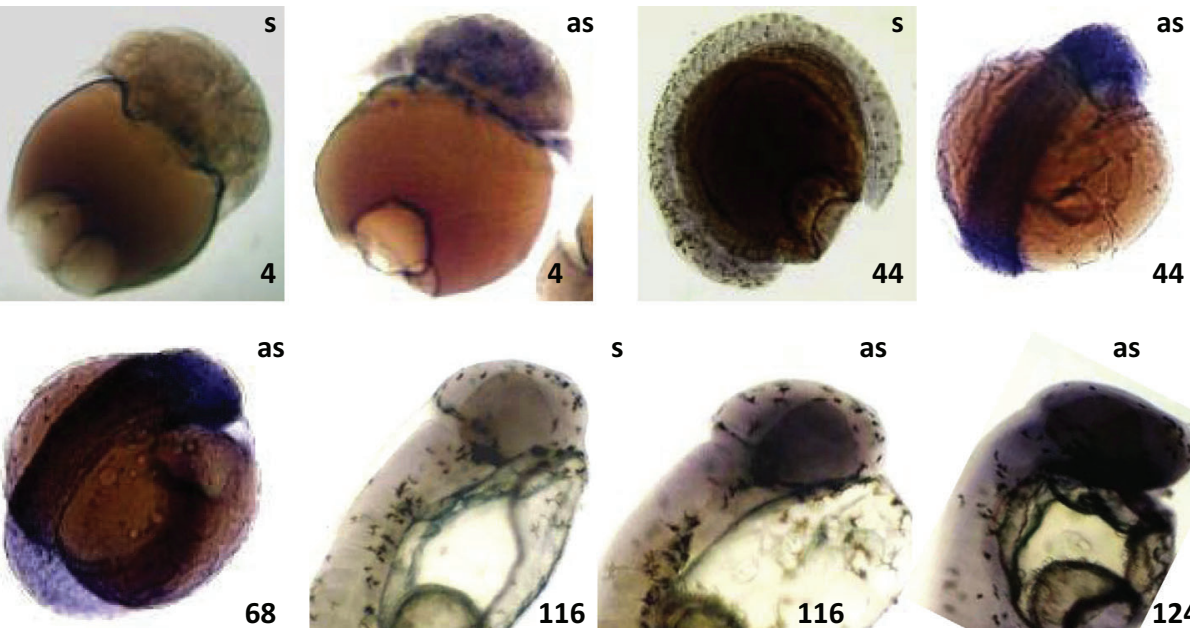

as

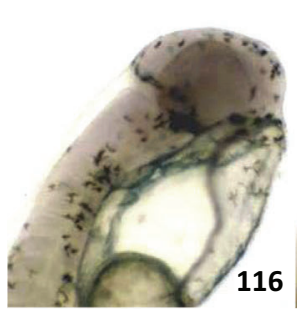

$\mathbf{S}$

as
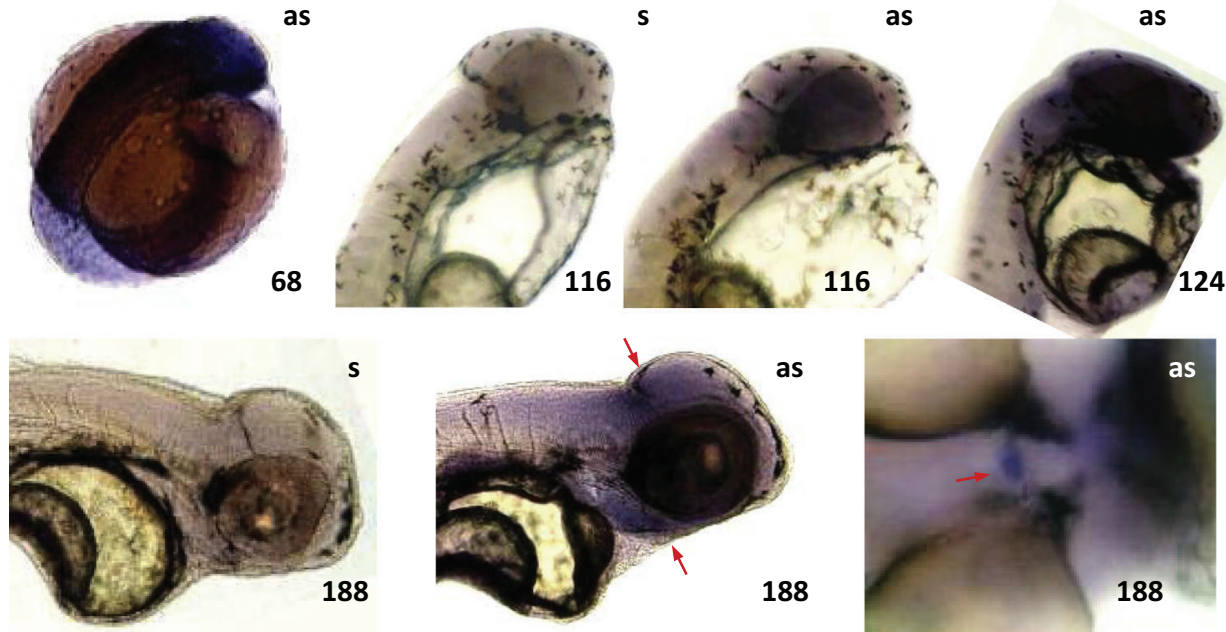

Fig. 3. Whole-mount ISH for GH mRNA during sea bass development. s: sense probe; as: antisense probe. Hours post-fertilization are indicated at the bottom of the picture.

Studies in the trout (Li et al., 2006) and sea bass (Cambre et al., 1990) had shown that the early presence of GH transcripts was not necessarily accompanied by detection of the corresponding protein. Here we demonstrate that the $\mathrm{dlGH}$-antibody used recognized a major band at $19 \mathrm{kDa}$ and another minor band at $20 \mathrm{kDa}$ in pituitary extracts, while in unfertilized eggs and embryos only the $19 \mathrm{kDa}$ band was detected with an additional minor band at $23 \mathrm{kDa}$. Twenty three $\mathrm{kDa}$ is the expected size of sea bass $\mathrm{GH}$

Please cite this article in press as: Laurence, B., et al. Somatotropic axis genes are expressed before pituitary onset during zebrafish and sea bass development. Gen. Comp. Endocrinol. (2013), http://dx.doi.org/10.1016/j.ygcen.2013.08.018 
$\begin{array}{llllll}-1 & 0 & 4 & 24 & 48 & 72\end{array}$
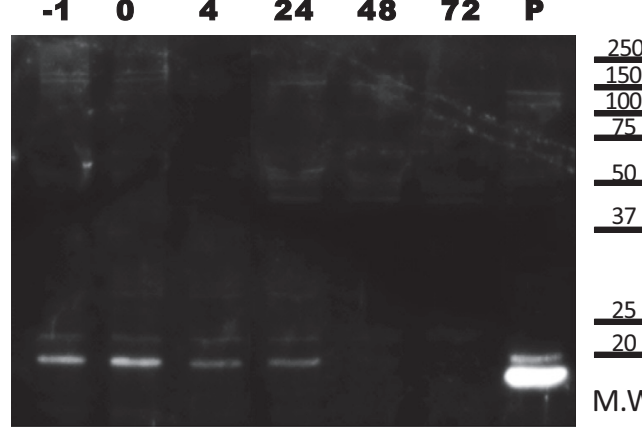

$\begin{array}{lllllll}96 & 120 & 144 & 168 & 192 & 288 & P\end{array}$

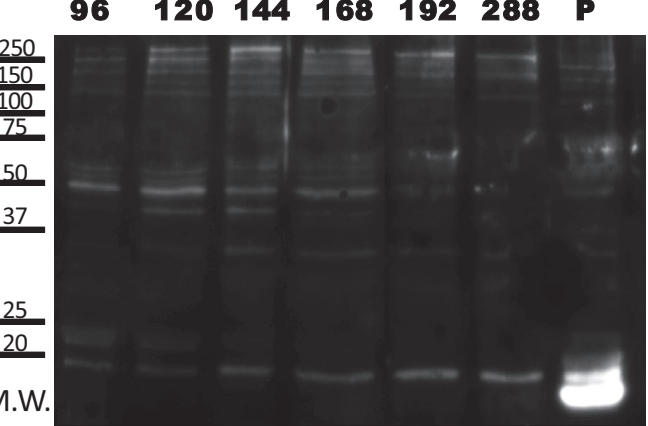

Fig. 4. Western blot analysis of GH protein from developing sea bass embryos and larvae. Hours post-fertilization are indieation at the top ( -1 : unfertilized eggs, 0: fertilization); P: pituitary extract; M.W.: molecular weight markers.
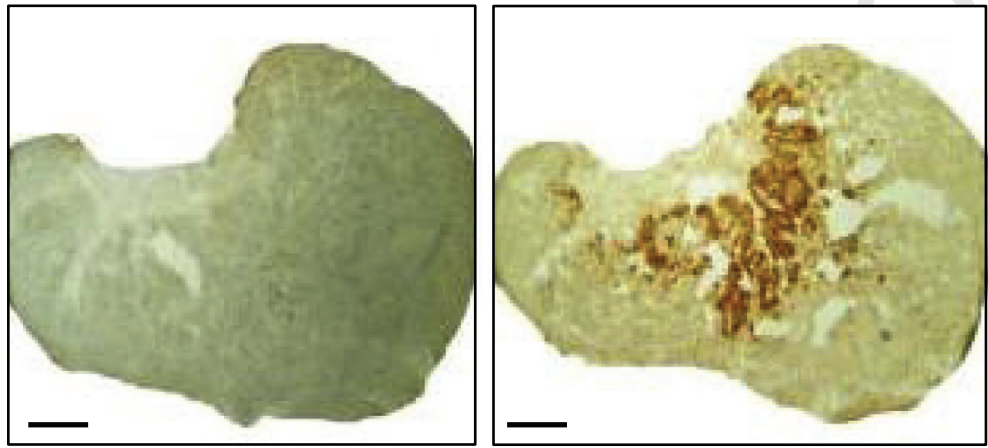

Fig. 5. Immunocytochemical detection of a GH like protein in a section from a sea bass pituitary (right). Control section (left) (Bar: $150 \mu \mathrm{m}$ ). errors in the legends. 3 legends are lacking: 24,48 and hpf for $D$ rerio

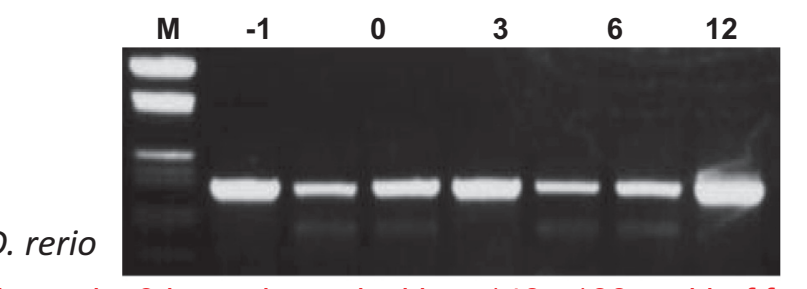

errors in the legends. $3_{M}$ legends are facking: $148_{28} 188_{52}$ nd $h_{196}$ for D la lost legends are here II

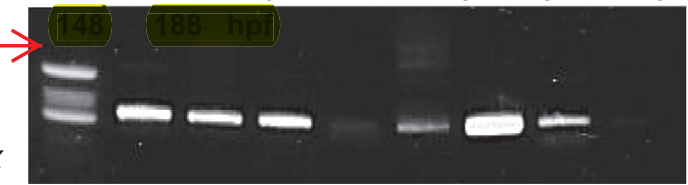

Fig. 6. Expression of $\mathrm{GH}$ receptor mRNA in extracts from Danio rerio and Dicentrarchus labrax unfertilized $(-1)$ and fertilized (0) eggs and embryos at different hours post-fertilization (hpf). RT-PCR. M: markers.

protein, deduced from the peptide sequence. There are reasons to believe the 19 and $20 \mathrm{kDa}$ bands also correspond to GH. First the antibody identified the bands specifically in pituitary extracts. Second, this antibody labeled only the GH producing cells in ICC from pituitary sections (identified by their location in the tissue (Cambre et al., 1986). Third, in enzyme-linked immune-absorbent assays (ELISA) the immunogen peptides or media dilutions from cultured pituitary glands displaced linearly antibody binding (not shown). Finally the co-existence of several forms of GH has been shown in tetrapods as a result either of gene duplication or expression of splice variants or post-translational modifications of the native protein (Aramburo et al., 2000; Komatsu et al., 2007). Although gene duplication is common in Teleost fish, there is to date no evidence for the presence of two GH in sea bass as is the case in zebrafish, and in contrast with trout (Gabillard et al., 2003). We therefore believe that the bands detected in this study at 19 and at $20 \mathrm{kDa}$ result from proteolytic cleavage of a native $23 \mathrm{kDa}$ protein, as observed in the chicken and human GH (Aramburo et al., 2000; Komatsu et al., 2007). Interestingly, the Western blots from sea bass extracts suggest that the cleavage operates at different levels during development: a major $(20 \mathrm{kDa})$ and a minor (23 kDa) band were detected in eggs and embryos up to $24 \mathrm{hpf}$, abripy the $20 \mathrm{kDa}$ band remained from 144 to $288 \mathrm{hpf}$ while adults extracts display again two bands but at 20 and $19 \mathrm{kDa}$. Ontogenetic changes in the proportions of the different variants have already been reported to occur in chicken (Aramburo et al., 2000). The transient appearance of bands at higher molecular weights (40$50 \mathrm{kDa}$ ) between 96 and $168 \mathrm{hpf}$ might reflect the presence of GH dimers of different cleavage products, as reported for tetrapods (Aramburo et al., 2000; Grigorian et al., 2005; Luna et al., 2004). The decrease in bands intensity observed from 0 to 48 hpf and disappearance at 48 and $72 \mathrm{hpf}$ might correspond to the extinction of GH material from maternal origin followed at $86 \mathrm{hpf}$ and onwards by endogenous production. Altogether our results suggest that $\mathrm{GH}$ transcripts translate into GH protein in the developing embryo. The low levels detected by Western blot could explain that ICC methods did not allow detection of GH cells before pituitary formation in sea bass (Cambre et al., 1990) and other species (Li et al., 2005; Ozaki et al., 2006).

A GH protein being present at the stages investigated, it was of interest to investigate the expression of the corresponding receptors. GHR have been identified in several fish species, and two forms are reported to exist (Di Prinzio et al., 2010; Ozaki et al., 2006; Saera-Vila et al., 2005, 2009). In zebrafish, expression of receptors (GHRa and GHRb) was detected at all stages investigated except at 96 hpf (Di Prinzio et al., 2010). Our results agree with these data and extend to sea bass the conclusion that GHR are 


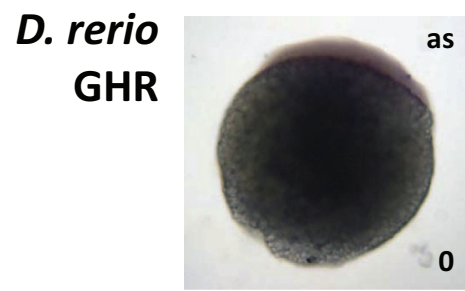

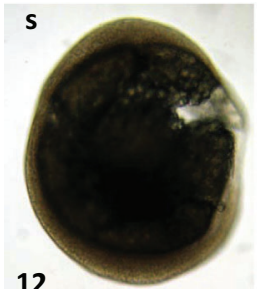

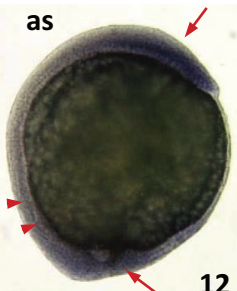

12
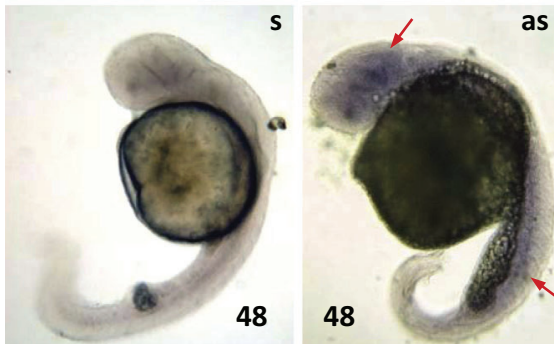
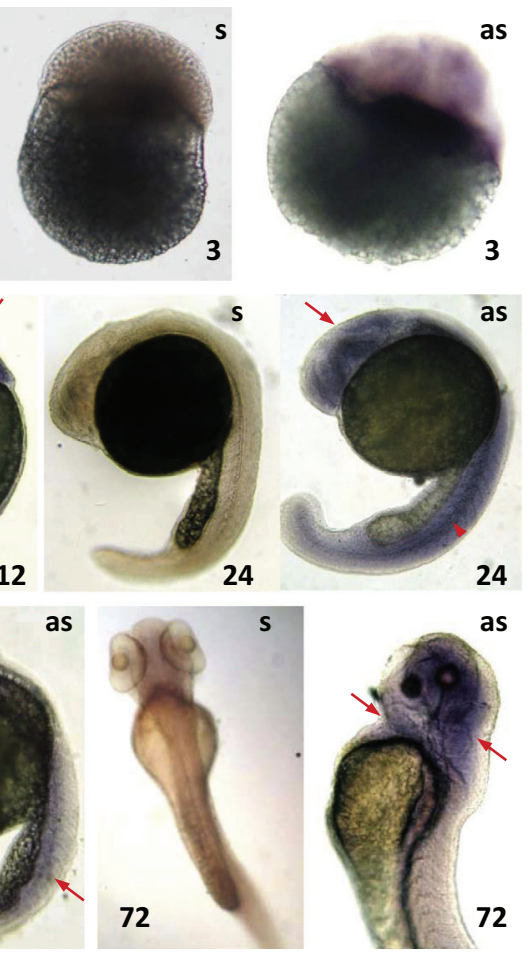

Fig. 7. Whole-mount ISH for GH receptor mRNA during zebrafish development. s: sense probe; as: antisense probe. Hours post-fertilization are indicated at the bottom of the picture.
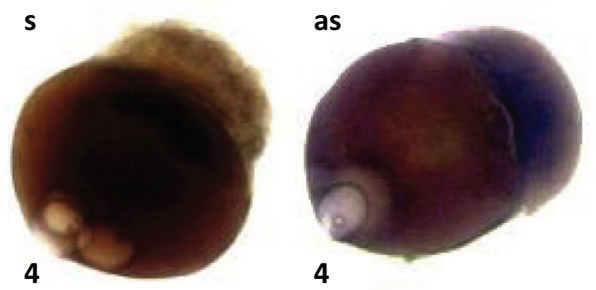

\section{D. labrax}

\section{GHR}
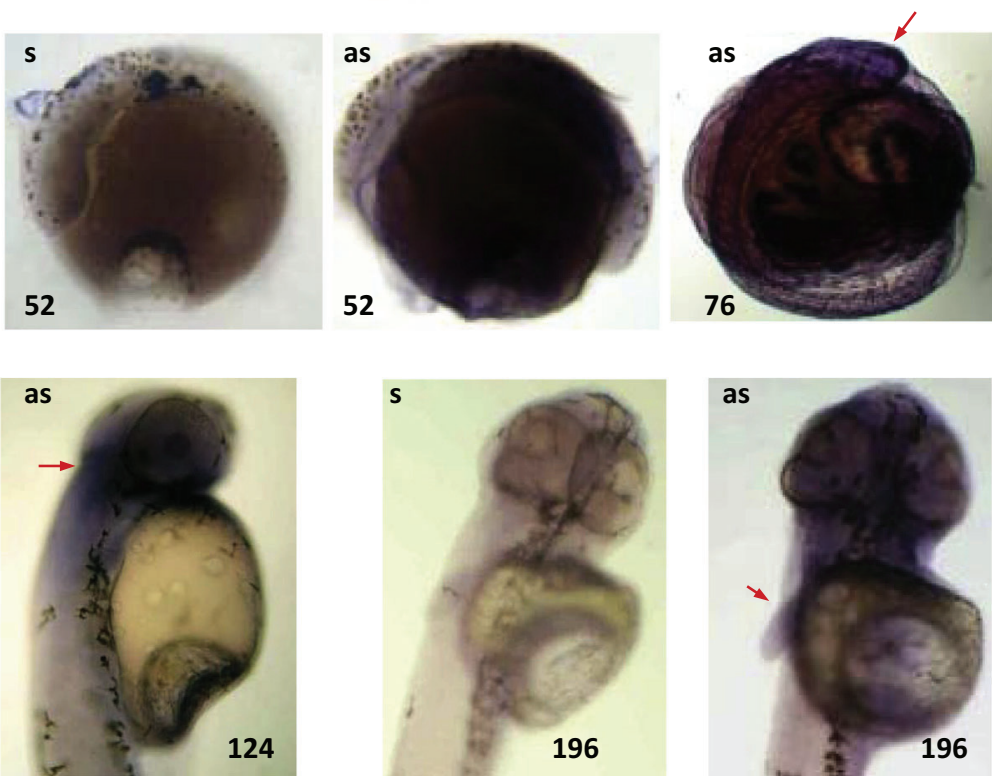

Fig. 8. Whole-mount ISH for GH receptor mRNA during sea bass development. s: sense probe; as: antisense probe. Hours post-fertilization are indicated at the bottom of the picture. 

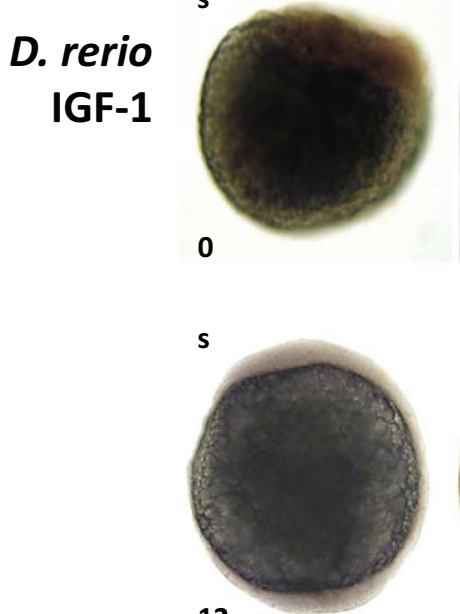

12

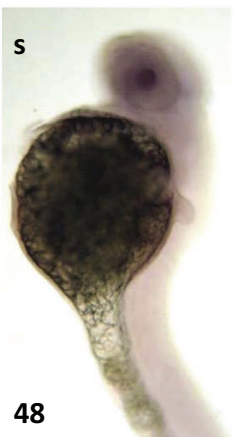



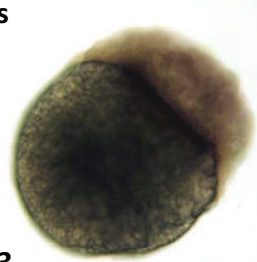

3



24

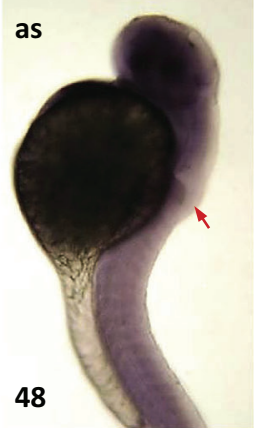

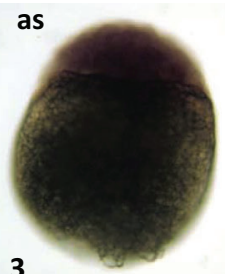
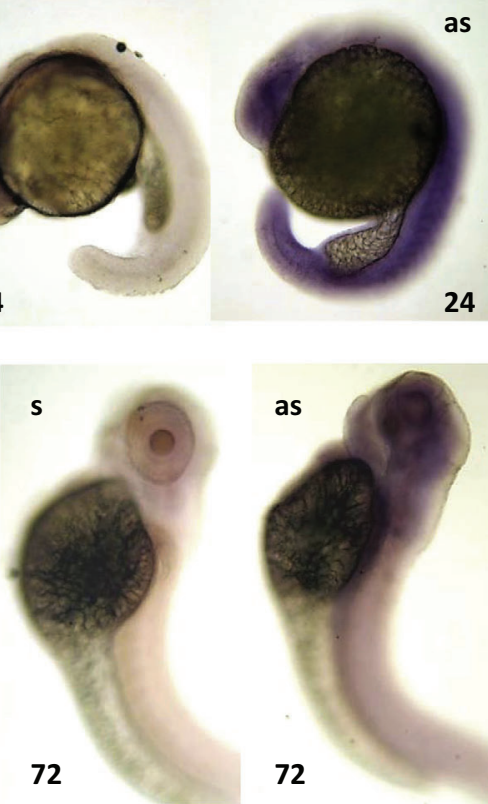

Fig. 9. Whole-mount ISH for IGF-1 mRNA during zebrafish development. s: sense probe; as: antisense probe. Hours post-fertilization are indicated at the bottom of the picture.

\section{D. labrax IGF-1}
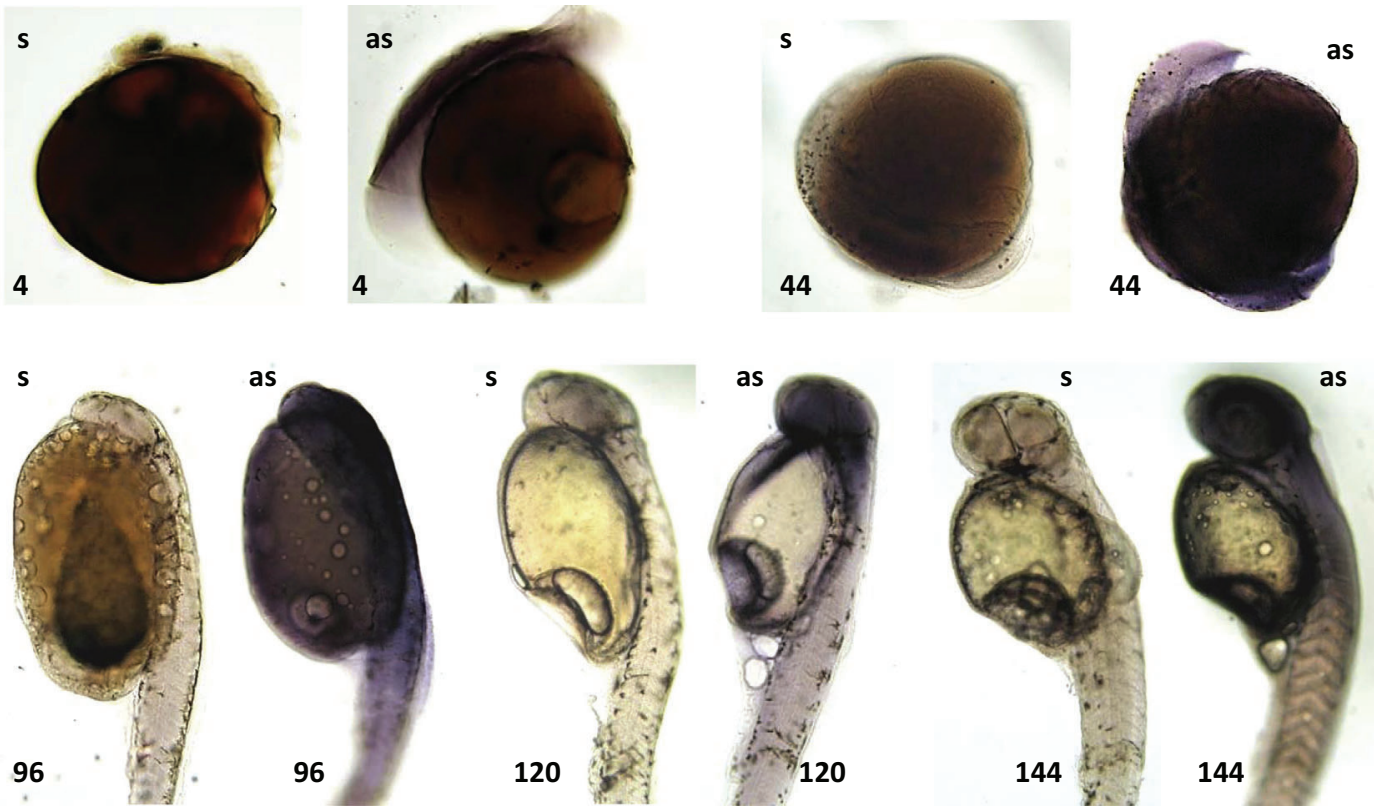

Fig. 10. Whole-mount ISH for IGF-1 mRNA during sea bass development. s: sense probe; as: antisense probe. Hours post-fertilization are indicated at the bottom of the picture. 
expressed from fertilization. GHR transcripts had been detected in immature oocytes of tilapia (Oreochromis mossambicus) (Kajimura et al., 2004) and Japanese eel (Ozaki et al., 2006), but their presence has not been described in embryonic stages. An early expression of GHR in zebrafish was previously surprising in view of the fact that no GH expression had been demonstrated before $42 \mathrm{hpf}$ in zebrafish (Herzog et al., 2003). Our current data on zebrafish and sea bass suggest that a functional GH/GHR system is present from unfertilized and fertilized eggs. It is noteworthy that sea bass GHR expression detected both by RT-PCR and ISH seemed to be lower at 28 and $52 \mathrm{hpf}$, perhaps reflecting extinction of the maternal transcripts.

Many of the growth promoting effects of $\mathrm{GH}$ are believed to be mediated by IGF-1 (Funkenstein et al., 2002). Members of the IGF family, including IGF-1, have been cloned in various Teleost fish, but their developmental expression pattern has been investigated only in a very few of them (Berishvili et al., 2006; Escobar et al. 2011; Li et al., 2005; Patruno et al., 2008; Perrot et al., 1999; Reinecke, 2010; Wood et al., 2005; Zou et al., 2009). If GH and GHR are determinant for the expression of IGF-1 as generally admitted (Duval et al., 2002; Sanders and Harvey, 2004) one would expect IGF-1 expression to be concomitant to GH and GHR expression. Whereas this is the case in trout (Li et al., 2006), discrepancies have been reported to exist in other species. Thus, the first GH transcripts and a GH-like protein were seen three days post-hatchand first feeding (Funkenstein and Cohen, 1996), while expressions of IGFs and IGFBPs were detected in unfertilized eggs and embryos (Perrot et al., 1999). It was concluded that IGF-1 expression might be $\mathrm{GH}$ independent at early stages. A similar lag between the $\mathrm{GH}$ (Herzog et al., 2003) and IGF-1 (Chen et al., 2001; Zou et al., 2009) onsets of expression has been reported in zebrafish where two IGF-1 ( $a$ and $b$ ) have been cloned; IGF-1b is expressed from fertilization and onwards, and IGF-1a shortly after (Zou et al., 2009). The zebrafish 630 mers long IGF-1 probe used in this study covered a sequence corresponding to IGF-1a that differed from IGF$1 \mathrm{~b}$ mainly by 20 mers at each end (i.e., 40 mers in total). It is therefore possible that it might have labeled both IGF-1a and IGF-1b forms. Whatever it may be, our data indicate that IGF-1 was expressed in eggs, embryo and larvae as was the case for $\mathrm{GH}$ and GHR. And we extend this conclusion to the developing sea bass in contradiction with a previous study that reported IGF-1 expression starting in the liver at dph 6 (Patruno et al., 2008).

Previous studies have suggested that either GH, or GHR or IGF act on fish development in an autocrine and/or paracrine manner (Berishvili et al., 2006; Escobar et al., 2011; Patruno et al., 2008). Our results show that all three components from maternal origin are present in the unfertilized egg and during the first hours of development, and are produced as soon as endogenous transcription starts. This strongly supports the view that the GH/GHR/IGF axis is functional at the very early stages of development, playing a role in fish development and differentiation. GH and IGF might have proper actions before transcription starts in the embryo. Put together, our results agree with the hypothesis that the system is important for the development of the anterior and posterior parts of the larvae and particularly of the nervous system, muscle and bone related structures, as suggested for the role of IGF in the Chilean flounder Paralichtys adsperus (Escobar et al., 2011) and zebrafish D. rerio (Eivers et al., 2004; Zou et al., 2009).

In conclusion, we have shown for the first time that transcripts corresponding to GH, GHR and IGF are inherited and present during early development in zebrafish and sea bass. Our results highlight that the discrepancies regarding onset of GH expression in fish may just result from technical issues. The presence of the GH protein, as shown in sea bass, further supports the idea that $\mathrm{GH}$ is important for the early function of the GH/GHR/IGF system. ing in the sea bream, coincident with the end of yolk absorption
To date GH knocked-down experiments performed by us (not shown) and others (Zhu et al., 2007) did not lead to any discernible change. Thus, further experimentation is needed in order to precisely determine the role GH/GHR/IGF-1 axis plays in early development of fish.

\section{Acknowledgments}

We thank Julie Francès, Marine Lansard, Eric Gasset and Stéphane Lallemand for their technical assistance. This work was supported by the GDR 2821 (CNRS, IFREMER, UJM and UPMC).

\section{Appendix A. Supplementary data}

Supplementary data associated with this article can be found, in the online version, at http://dx.doi.org/10.1016/j.ygcen.2013.08. 018 .

\section{References}

Aramburo, C., Luna, M., Carranza, M., Reyes, M., Martinez-Coria, H., Scanes, C.G., Q 2000. Growth hormone size variants: changes in the pituitary during development of the chicken. Proc. Soc. Exp. Biol. Med. 223, 67-74.

Ayson, F.G., Kaneko, T., Hasegawa, S., Hirano, T., 1994. Differential expression of 2 prolactin and growth-hormone genes during early development of tilapia (Oreochromis mossambicus) in fresh-water and seawater - implications for possible involvement in osmoregulation during early-life stages. Gen. Comp. Endocrinol. 95, 143-152.

Barnabé, G., Boulineaucoatanea, F., Rene, F., 1976. Chronology of morphogenesis in Dicentrarchus Labrax L. (Pisces Serranidae) obtained by artificial reproduction. Aquaculture 8, 351-363.

Berishvili, G., D'Cotta, H., Baroiller, J.F., Segner, H., Reinecke, M., 2006. Differentia expression of IGF-I mRNA and peptide in the male and female gonad during early development of a bony fish, the tilapia Oreochromis niloticus. Gen. Comp. Endocrinol. 146, 204-210.

Bradford, M.M., 1976. A rapid and sensitive method for the quantitation of microgram quantities of protein utilizing the principle of protein-dye binding. Anal. Biochem. 72, 248-254.

Cambre, M.L., Verdonck, W., Ollevier, F., Vandesande, F., Batten, T.F.C., Kuhn, E.R., 1986. Immunocytochemical identification and localization of the different celltypes in the pituitary of the sea bass (Dicentrarchus labrax). Gen. Comp. Endocrinol. 61, 368-375.

Cambre, M., Mareels, G., Corneillie, S., Moons, L., Ollevier, F., Vandesande, F., 1990 Chronological appearance of the different hypophyseal hormones in the pituitary of sea bass larvae (Dicentrarchus labrax) during their early development - an immunocytochemical demonstration. Gen. Comp. Endocrinol. 77, 408-415.

Chen, W.T., Ge, W., 2012. Ontogenic expression profiles of gonadotropins (FSHb and $\mathrm{LHb}$ ) and growth hormone ( $\mathrm{GH}$ ) during sexual differentiation and puberty onset in female zebrafish. Biol. Reprod. 86, 73.

Chen, M.H.C., Lin, G.H., Gong, H.Y., Weng, C.F., Chang, C.Y., Wu, J.L., 2001. The characterization of prepro-insulin-like growth factor-1 Ea-2 expression and insulin-like growth factor-1 genes (devoid $81 \mathrm{bp}$ ) in the zebrafish (Danio rerio). Gene 268, 67-75.

Di Prinzio, C.M., Botta, P.E., Barriga, E.H., Rios, E.A., Reyes, A.E., Arranz, S.E., 2010. Growth hormone receptors in zebrafish (Danio rerio): adult and embryonic expression patterns. Gene Expr. Patterns 10, 214-225.

Duval, H., Rousseau, K., Elies, G., Le Bail, P.Y., Dufour, S., Boeuf, G., et al., 2002. Cloning, characterization, and comparative activity of turbot IGF-I and IGF-II. Gen. Comp. Endocrinol. 126, 269-278.

Eivers, E., McCarthy, K., Glynn, C., Nolan, C.M., Byrnes, L., 2004. Insulin-like growth factor (IGF) signalling is required for early dorso-anterior development of the zebrafish embryo. Int. J. Dev. Biol. 48, 1131-1140.

Escobar, S., Fuentes, E.N., Poblete, E., Valdes, J.A., Safian, D., Reyes, A.E., et al., 2011 Molecular cloning of IGF-1 and IGF-1 receptor and their expression pattern in the Chilean flounder (Paralichthys adspersus). Comp. Biochem. Physiol. B Biochem. Mol. Biol. 159, 140-147.

Falcón, J., Besseau, L., Fazzari, D., Attia, J., Gaildrat, P., Beauchaud, M., et al., 2003. Melatonin modulates secretion of growth hormone and prolactin by trout pituitary glands and cells in culture. Endocrinology 144, 4648-4658.

Fuentes, E., Poblete, E., Reyes, A.E., Vera, M.I., Alvarez, M., Molina, A., 2008. Dynamic expression pattern of the growth hormone receptor during early development of the Chilean flounder. Comp. Biochem. Physiol. B Biochem. Mol. Biol. 150, 93102.

Funkenstein, B., Cohen, I., 1996. Ontogeny of growth hormone protein and mRNA in the gilthead sea bream Sparus aurata. Growth Regul. 6, 16-21.

Funkenstein, B., Tsai, W., Maures, T., Duan, C., 2002. Ontogeny, tissue distribution, and hormonal regulation of insulin-like growth factor binding protein-2 (IGFBP2 ) in a marine fish, Sparus aurata. Gen. Comp. Endocrinol. 128, 112-122. 
Gabillard, J.C., Duval, H., Cauty, C., Rescan, P.Y., Weil, C., Le Bail, P.Y., 2003. Differential expression of the two GH genes during embryonic development of rainbow trout Oncorhynchus mykiss in relation with the IGFs system. Mol. Reprod. Dev. 64, 32-40.

Grigorian, A.L., Bustamante, J.J., Hernandez, P., Martinez, A.O., Haro, L.S., 2005. Extraordinarily stable disulfide-linked homodimer of human growth hormone. Protein Sci. 14, 902-913.

Herrero-Turrión, M.J., Rodriguez, R.E., Velasco, A., Gonzalez-Sarmiento, R., Aijon, J., Lara, J.M., 2003. Growth hormone expression in ontogenic development in gilthead sea bream. Cell Tissue Res. 313, 81-91.

Herzog, W., Zeng, X.C., Lele, Z., Sonntag, C., Ting, J.W., Chang, C.Y., et al., 2003. Adenohypophysis formation in the zebrafish and its dependence on Sonic hedgehog. Dev. Biol. 254, 36-49.

Jones, I., Kille, P., Sweeney, G., 2001. Cadmium delays growth hormone expression during rainbow trout development. J. Fish Biol. 59, 1015-1022.

Kajimura, S., Kawaguchi, N., Kaneko, T., Kawazoe, I., Hirano, T., Visitacion, N., et al., 2004. Identification of the growth hormone receptor in an advanced teleost, the tilapia (Oreochromis mossambicus) with special reference to its distinct expression pattern in the ovary. J. Endocrinol. 181, 65-76.

Kimmel, C.B., Ballard, W.W., Kimmel, S.R., Ullmann, B., Schilling, T.F., 1995. Stages of embryonic development of the zebrafish. Dev. Dyn. 203, 253-310.

Komatsu, N., Saijoh, K., Otsuki, N., Kishi, T., Micheal, I.P., Obiezu, C.V., et al., 2007. Proteolytic processing of human growth hormone by multiple tissue kallikreins and regulation by the serine protease inhibitor Kazal-Type5 (SPINK5) protein. Clin. Chim. Acta 377, 228-236.

Li, W.S., Chen, D., Wong, A.O.L., Lin, H.R., 2005. Molecular cloning, tissue distribution, and ontogeny of mRNA expression of growth hormone in orange-spotted grouper (Epinephelus coioides). Gen. Comp. Endocrinol. 144, 78-89.

Li, M., Greenaway, J., Rame, J., Petrik, J., Hahnel, A., Leatherland, J., 2006. Growth hormone and insulin-like growth factor gene expression prior to the development of the pituitary gland in rainbow trout (Oncorhynchus mykiss) embryos reared at two temperatures. Comp. Biochem. Physiol. A Mol. Integr. Physiol. 143, 514-522.

Li, X., He, J., Hu, W., Yin, Z., 2009. The essential role of endogenous ghrelin in growth hormone expression during zebrafish adenohypophysis development. Endocrinology 150, 2767-2774.

Luna, M., Huerta, L., Berumen, L., Martinez-Coria, H., Harvey, S., Aramburo, C., 2004. Growth hormone in the male reproductive tract of the chicken: heterogeneity and changes during ontogeny and maturation. Gen. Comp. Endocrinol. 137, 3749.

Martoja, R., Martoja, M., 1967. Initiation aux techniques de l'histologie animale. Masson, Paris.

Miura, C., Shimizu, Y., Uehara, M., Ozaki, Y., Young, G., Miura, T., 2011. GH is produced by the testis of Japanese eel and stimulates proliferation of spermatogonia. Reproduction 142, 869-877.

Moriyama, S., Ayson, F.G., Kawauchi, H., 2000. Growth regulation by insulin-like growth factor-I in fish. Biosci. Biotechnol. Biochem. 64, 1553-1562.

Murphy, A.E., Harvey, S., 2001. Extrapituitary beta TSH and GH in early chick embryos. Mol. Cell. Endocrinol. 185, 161-171.

Ozaki, Y., Fukada, H., Tanaka, H., Kagawa, H., Ohta, H., Adachi, S., et al., 2006. Expression of growth hormone family and growth hormone receptor during early development in the Japanese eel (Anguilla japonica). Comp. Biochem. Physiol. B Biochem. Mol. Biol. 145, 27-34.
Pantaleon, M., Whiteside, E.J., Harvey, M.B., Barnard, R.T., Waters, M.J., Kaye, P.L., 1997. Functional growth hormone $(\mathrm{GH})$ receptors and $\mathrm{GH}$ are expressed by preimplantation mouse embryos: a role for $\mathrm{GH}$ in early embryogenesis? Proc. Nat. Acad. Sci. USA 94, 5125-5130.

Patruno, M., Sivieri, S., Poltronieri, C., Sacchetto, R., Maccatrozzo, L., Martinello, T., et al., 2008. Real-time polymerase chain reaction, in situ hybridization and immunohistochemical localization of insulin-like growth factor-I and myostatin during development of Dicentrarchus labrax (Pisces: Osteichthyes). Cell Tissue Res. 331, 643-658.

Perez-Sanchez, J., 2000. The involvement of growth hormone in growth regulation, energy homeostasis and immune function in the gilthead sea bream (Sparus aurata): a short review. Fish Physiol. Biochem. 22, 135-144.

Perrot, V., Moiseeva, E.B., Gozes, Y., Chan, S.J., Ingleton, P., Funkenstein, B., 1999. Ontogeny of the insulin-like growth factor system (IGF-I, IGF-II, and IGF-1R) in gilthead seabream (Sparus aurata): expression and cellular localization. Gen. Comp. Endocrinol. 116, 445-460.

Pogoda, H.-M., Hammerschmidt, M., 2009. How to make a teleost adenohypophysis: molecular pathways of pituitary development in zebrafish. Mol. Cell. Endocrinol. 312, 2-13.

Reinecke, M., 2010. Influences of the environment on the endocrine and paracrine fish growth hormone-insulin-like growth factor-I system. J. Fish Biol. 76, 12331254.

Reinecke, M., Bjornsson, B.T., Dickhoff, W.W., McCormick, S.D., Navarro, I., Power, D.M., et al., 2005. Growth hormone and insulin-like growth factors in fish: where we are and where to go. Gen. Comp. Endocrinol. 142, 20-24.

Revol, A.S., Rodriguez, M.D.G., Montenegro, V.H., Aguilera, C., Saldana, H.B., Mendoza, R., 2005. Cloning of the growth hon-none cDNA of alligator gar Atractosteus spatula and its expression through larval development. Comp. Biochem. Physiol. A Mol. Integr. Physiol. 140, 423-429.

Saera-Vila, A., Calduch-Giner, J.A., Perez-Sanchez, J., 2005. Duplication of growth hormone receptor (GHR) in fish genome: gene organization and transcriptional regulation of GHR type I and II in gilthead sea bream (Sparus aurata). Gen. Comp. Endocrinol. 142, 193-203.

Saera-Vila, A., Calduch-Giner, J.A., Prunet, P., Perez-Sanchez, J., 2009. Dynamics of liver $\mathrm{GH} / \mathrm{IGF}$ axis and selected stress markers in juvenile gilthead sea bream (Sparus aurata) exposed to acute confinement differential stress response of growth hormone receptors. Comp. Biochem. Physiol. A Mol. Integr. Physiol. 154, 197-203.

Sanders, E.J., Harvey, S., 2004. Growth hormone as an early embryonic growth and differentiation factor. Anat. Embryol. 209, 1-9.

Volckaert, F.A.M., Mugoyo, J.W.M., Lescroart, O., Grisez, L., Ollevier, F, 1999. Immunohistochemically detected ontogeny of prolactin and growth hormone cells in the African catfish Clarias gariepinus. Comp. Biochem. Physiol. B Biochem. Mol. Biol. 122, 423-431.

Wood, A.W., Duan, C.M., Bern, H.A., 2005. Insulin-like growth factor signaling in fish. Int. Rev. Cytol., 215-285.

Yang, B.Y., Green, M., Chen, T.T., 1999. Early embryonic expression of the growth hormone family protein genes in the developing rainbow trout, Oncorhynchus mykiss. Mol Reprod. Dev. 53, 127-134.

Zhu, Y., Song, D., Tran, N.-T., Nguyen, N., 2007. The effects of the members of growth hormone family knockdown in zebrafish development. Gen. Comp. Endocrinol. $150,395-404$.

Zou, S., Kamei, H., Modi, Z., Duan, C., 2009. Zebrafish IGF genes: gene duplication, conservation and divergence, and novel roles in midline and notochord development. PLoS ONE 4, e7026, doi:7010.1371/journal.pone.0007026. 